\title{
A probabilistic approach to the seismic hazard in Kashmir basin, NW Himalaya
}

\author{
Hamid Sana* (10
}

\begin{abstract}
Northwestern Himalaya is one of the most tectonically active domains of the Himalayan arc. The prevailing complex collisional tectonic setup is able to produce destructive earthquakes, most recent being the 8 October 2005 Kashmir earthquake (M7.6). In this study, the probabilistic seismic hazard assessment of the Kashmir basin of northwestern Himalaya is presented. The seismic hazard is assessed using point, areal and linear source models employing appropriate ground motion prediction equations to predict the expected ground motions. The seismic hazard maps are expressed in terms of $\mathrm{g}$, seismic hazard curves at $2 \%$ and $10 \%$ probability of exceedance in 50 years and the design response spectra at 5\% damping for four major towns of the basin at the engineering bedrock. The results are expressed as the hypocentral depth-wise hazard maps, predicted peak ground acceleration (PGA), pseudo-spectral acceleration (PSA) with $2 \%$ and $10 \%$ probability of exceedance within 50 years and the design response spectra with $5 \%$ damping of four major towns of Kashmir for engineering bedrock sites. The hypocentral depth-wise maps are shown in the ranges of $0-25 \mathrm{~km}, 25-70 \mathrm{~km}$ and $>70 \mathrm{~km}$ with $10 \%$ probability of exceedance in 50 years. The computation is based on smoothly gridded seismicity for each depth zone with a return period of 475 years. With the seismic source zones considered as sources, the seismic hazard maps show predicted peak ground acceleration (PGA) and pseudo-spectral acceleration (PSA) with $2 \%$ and $10 \%$ probability of exceedance within 50 years for engineering bedrock sites. The PSA maps are expressed in $g$ at 0.2 and $1 \mathrm{~s}(\mathrm{~s})$. From this preliminary study it is evident that overall Kashmir basin shows a very high seismic hazard, with southeastern part showing relatively higher hazard as compared to northwestern part. Among the major benchmark towns all show high predicted PGA, Anantnag shows the highest $(0.65 \mathrm{~g})$. The present study thus advocates a significantly higher seismic hazard as compared to the BIS In: IS 1893-2002 (Part 1): Indian standard criteria for earthquake resistant design of structures, Part 1-general provisions and buildings, (2002).
\end{abstract}

Keywords: Seismic hazard, Kashmir basin, Probabilistic seismic hazard analysis

\section{Introduction}

Seismic hazard refers to the probability of certain level of ground shaking in a given period of time. The effective ground motion is usually expressed as peak ground acceleration $(g)$, and the assessment is either carried out by deterministic or probabilistic approach. In the deterministic method, a maximum credible earthquake likely to occur in the vicinity of the site of interest is estimated and the maximum credible level of ground motion is

\footnotetext{
*Correspondence: ibnsana@gmail.com; sana@irsm.cas.cz Department of Neotectonics and Thermochronology, Institute of Rock Structure and Mechanics, Czech Academy of Sciences, Prague, Czech Republic
}

determined. While as in the probabilistic assessment, numerical probabilities are assigned to earthquake occurrences and their effects during a specific time period, such as the life of a given engineering structure (Yeats et al. 1997; Suckale et al. 2005). Usually earthquake catalogue is used as the primary probabilistic tool for projecting future events (Cornell 1968) but some seismic hazard assessment studies like Ward (1994) have used GPS data also. The basic foundations of the probabilistic seismic hazard assessment (PSHA) methodology were overlain by Cornell (1968) and McGuire (1976); since then there have been various modifications and developments in this basic framework. Cornell (1971) modified his earlier method (Cornell 1968) by introducing the concept 
of ground motion uncertainty, which is explained as the fact that ground motion could be different for two different earthquakes of the same magnitude occurring at the same distance. Zone free approach of Woo (1996) and Kramer's (1996) incorporation of ground motion prediction equations (GMPE) with standard deviation in the probability calculation are also significant developments. Finally, uncertainties are taken into account in the framework by a weighted sum of various seismic source models, GMPEs and other seismicity parameters.

In the probabilistic seismic hazard analysis, the collective effect of all the earthquakes of different magnitudes occurring at different locations produced by different earthquake sources at different probabilities of occurrence is integrated into a single hazard curve. It is assumed that the earthquakes follow the Poisson distribution. The hazard curve depicts the probability of exceeding different levels of ground motion, in this case peak ground acceleration $(g)$, during a specified period of time, which is represented as follows:

$$
E(Z)=\sum_{i=1}^{N} \alpha_{i} \int_{m_{\min }}^{m_{\max }} \int_{r_{\min }}^{r_{\max }} f_{i}(m) f_{r}(r) P(Z>z \mid m, r) \mathrm{d} r \mathrm{~d} m,
$$

where $E(Z)$ is the expected ground motion exceedance level $(z)$ during a specific time period $(t), \alpha_{i}$ is the mean rate of occurrence of earthquakes between lower $\left(m_{\min }\right)$ and upper bound magnitude $\left(m_{\max }\right), f_{i}(m)$ is the probability density distribution of magnitude with a specified source, $f_{r}(r)$ is the probability density distribution of epicentral distance between different locations with the specified source and the site of hazard estimation, and $P(Z>z \mid m, r)$ is the probability that an earthquake of magnitude $(m)$ with an epicentral distance of $(r)$ from the site will exceed the ground motion $(z)$, which is derived from the Gutenberg-Richter (G-R) relation (Guttenberg and Richter 1944). Finally, the logic tree framework is employed in the computation at each site to incorporate multiple models in source considerations, GMPEs and seismicity parameters.

In this study, the seismic hazard assessment of the Kashmir basin of northwestern Himalaya adopting the probabilistic approach is presented. It is the most populous division of the state of Jammu and Kashmir, home to about 7 million inhabitants. This basin is surrounded by faults which are capable of generating disastrous earthquakes (Fig. 1). These earthquakes are documented in the historical archives (e.g. Ambraseys and Douglas 2004; Ahmad et al. 2014) and recorded in the instrumental databases as well. The most recent of these earthquakes is the 8 October 2005 Kashmir earthquake with a magnitude $\left(M_{\mathrm{w}}\right)$ of 7.6. This earthquake caused widespread damage and destruction, triggering landslides and liquefaction and causing about 86,000 casualties and about 69,000 injuries (Avouac et al. 2006; Sana and Nath 2016a). Although Muzaffarabad was the worst affected area, northwestern part of the Kashmir Valley (Baramulla and Kupwara Districts) was also heavily affected, and 80 percent of the Uri town of Baramulla district was destroyed (Fig. 1). Overall, in the Kashmir region at least 32,335 buildings collapsed as a result of this earthquake (Hayes et al. 2017). So the motivation of this study to assess the seismic hazard of Kashmir basin is that the basin is not only a population center but there are large infrastructure projects like dams and tunnels underway or in future plan. Given the active tectonic setup in and around the basin capable to produce destructive earthquakes recorded in historical and recent earthquake records. The exposure of the population and infrastructure to the seismic hazard is very high and is underappreciated.

As per the national seismic hazard map of India (BIS 2002), Kashmir basin lies in Zone-V, which corresponds to the peak ground acceleration (PGA) of $0.4 \mathrm{~g}$. As far as the seismic hazard assessment is concerned, the firstorder deterministic seismic hazard assessment (DSHA) study of India was carried out by Parvez et al. (2003), wherein seismic hazard parameters were expressed in terms of design ground acceleration $(g)$, peak ground velocity $(\mathrm{cm} / \mathrm{s})$ and peak ground displacement $(\mathrm{cm})$. whereas the PSHA studies of India were conducted by Bhatia (1999) under Global Seismic Hazard Assessment Program (GSHAP) and recently by Nath and Thingbaijam (2012). In these studies, the hazard levels were presented as peak ground acceleration (PGA). But in order to assess the seismic hazard at regional level these studies conducted at much larger scale are not sufficient, so the results of these studies can be applied in the development of region-specific standard building code to design the earthquake resistant structures, land-use planning, hazard management, risk assessments and mitigation.

\section{Geologic and tectonic framework}

The Kashmir valley is a northwest-southeast directed tectonic basin in the northwestern Himalaya approximately $\sim 140 \mathrm{~km}$ long and $\sim 60 \mathrm{~km}$ wide. This intermountain Neogene-Quaternary basin is an important unit of the northwest Himalayan fold and thrust belt. The metamorphosed basement of this basin is overlain by thick fluvio-lacustrine (Cenozoic to Quaternary) sediments and surrounded by the peripheral Paleozoic and Mesozoic rocks (Kazmi and Jan 1977). The fluvio-lacustrine sediments are syn-orogenic and started depositing since last $\sim 4$ million years. These sediments are classified into Karewas and Riverine sediments, where the former are fluvio-lacustrine in origin and Plio-Pleistocene in age and 


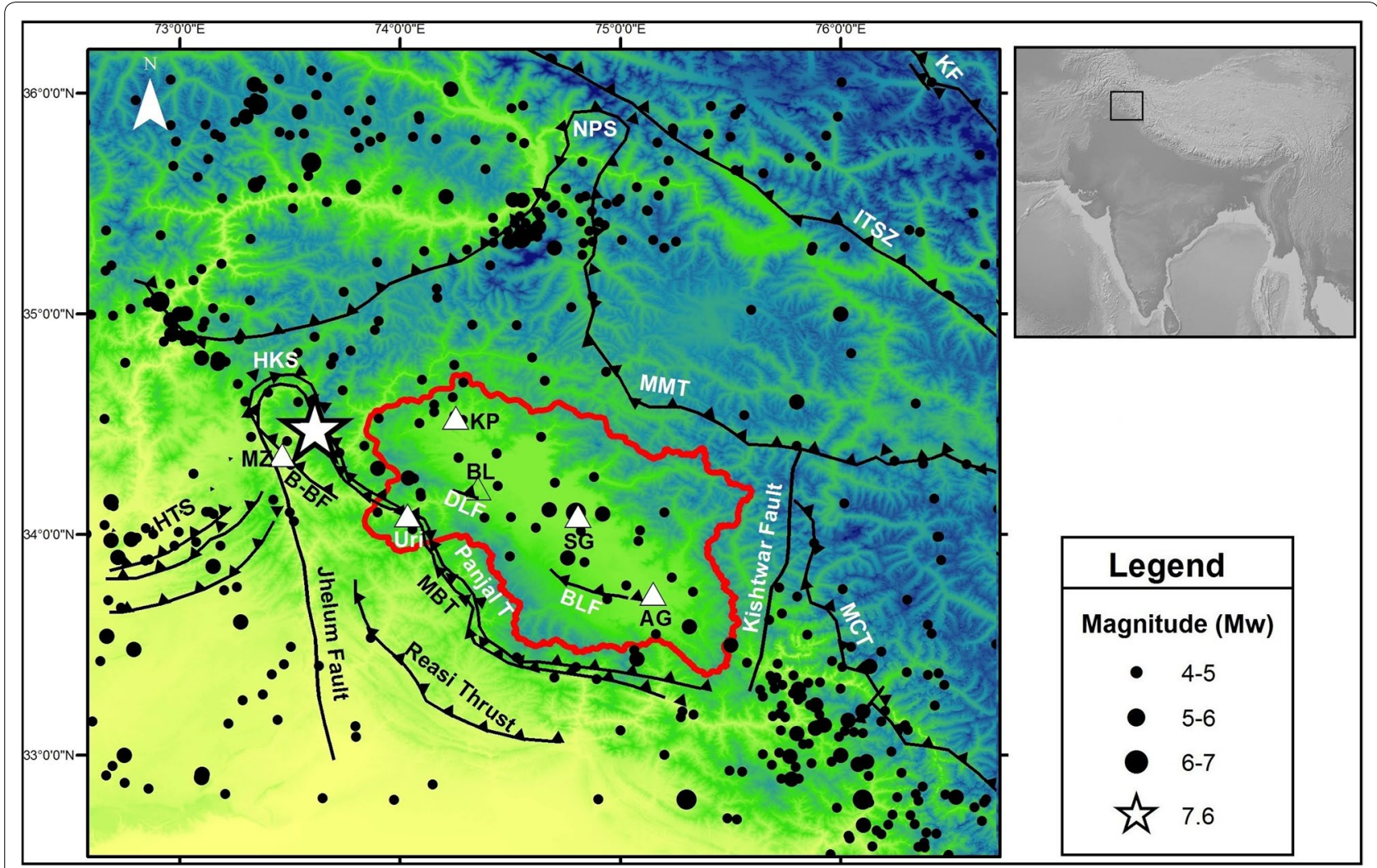

Fig. 1 Seismotectonic map of Kashmir Basin and surroundings with main tectonic features: Main Mantle Thrust (MMT), Main Crystalline Thrust (MCT), Main Boundary Thrust (MBT), Kishtwar Fault (KF), Panjal Thrust (PT), Reasi Thrust (RT), Jhelum Fault (JF), Bagh-Balakot Fault (B-BF), Hazara Thrust System (HTS), Balapur Fault (BF), Drangbal-Laridora Fault (DL), Hazara-Kashmir Syntaxis (HKS). Faults are from Dasgupta et al. (2000), BF from Ahmad et al. (2014) and DL from Sana and Nath (Sana and Nath 2016a, b). Star represents the epicenter of 8 October 2005 Kashmir earthquake $\left(M_{w}\right.$ 7.6)

later are riverine sediments of late Pleistocene-Holocene (Burbank and Johnson 1982, 1983; Burbank 1983; Bhatt 1989).

The Kashmir basin is surrounded by not only the main Himalayan boundary thrusts (Main Mantle Thrust, Main Central Thrust, Main Boundary Thrust and Panjal Thrust) Indus Tsangpo Suture Zone (ITSZ), Karakorum Fault (KF), Strike-slip Jhelum (JF), and Kishtwar Fault and the Hazara Thrust System (HTS), but also by active out-of-sequence fault, the Balakot-Bagh Fault $(\mathrm{B}-\mathrm{BF})$ and the stratigraphic equivalent of the $\mathrm{B}-\mathrm{BF}$, the Reasi Thrust (RT) as depicted in Fig. 1. The Main Mantle Thrust (MMT) is a main Himalayan thrust fault delineating the India-Eurasia plate boundary. The Main Boundary Thrust and Panjal Thrust loop around the Hazara-Kashmir Syntaxis (HKS) and run parallel along the southern margin of the Kashmir basin where former deforms the Precambrian rocks and the later deforms the formations of Oligocene-Miocene age, whereas the Main Central Thrust (MCT) is a $1.5 \mathrm{~km}$-wide ductile shear zone which separates the higher Himalayan crystalline rocks from the lower Himalayan formations. Apart from main boundary thrusts there are two important thrust systems worth mentioning: the Reasi Thrust (RT) and the Hazara Thrust System (HTS). To the south of MBT Holocene activity is reported from the Reasi Thrust (RT), whereas HTS refers to the collection of three thrusts to the west of HKS (Stephenson et al. 2001; Sana and Nath 2016a, b). The Karakorum Fault (KF) is a dextral strikeslip fault trending almost parallel to the NW Himalayan range (Chevalier et al. 2005). The nearly E-W trending Indus Tsangpo Suture Zone (ITSZ) is the suture which formed as a result of India-Eurasia collision (Xu et al. 2015). There are also two important local strike-slip faults in the seismo-tectonic domain of the study region, the north-south trending Jhelum Fault (JF), and high angle NE-dipping Kishtwar Fault (Sana and Nath 2016b). The out-of-sequence faults like the northeast-dipping Bagh-Balakot Fault (B-BF) cannot be overlooked from the seismotectonic point of view as they are capable of generating disastrous earthquakes in the Kashmir Himalaya like the 8 October 2005 Kashmir earthquake (Avouac 
et al. 2006). The seismo-tectonic map in and around the Kashmir basin is shown as Fig. 1.

\section{Dataset and methodology}

In order to accomplish the probabilistic seismic hazard analysis, classical methodology of Cornell (1968) and McGuire (1976) is adopted. There are four basic steps involved to accomplish the process:

(1) The definition and delineation of sources of seismicity sources which in this case is zone free (hypocentral depth-wise seismicity smoothened earthquake catalogue), seismic source zones and faults. (2) The establishment of the recurrence of the earthquake activity from the sources, where each source is described by a recurrence relationship. (3) The third step involves the estimation of ground motion, which is usually expressed as peak ground acceleration (PGA). (4) Finally, the computation of seismic hazard is carried out and is expressed in terms of exceedance curves. The exceedance curves depict the probability of exceeding different levels of ground motion during a specified period of time in the area of interest (Reiter 1990).

\section{Seismic sources and seismicity analysis}

In this study, the zone free (seismicity smoothened hypocentral depth-wise earthquake catalogue) and areal (seismogenic zones) sources and faults are used to generate hazard curves and maps. Sana and Nath (2017) have developed an extensive uniform magnitude earthquake catalogue of the Kashmir Himalaya and surroundings using different sources. This earthquake catalogue is published as a supplement to Sana and Nath (2016a, b). It encompasses the period from 1885 to 2012. It is compiled from various sources likes Jones (1885), Ambraseys (2000), Ambraseys and Bilham (2003), Ambraseys and Douglas (2004), Szeliga et al. (2010), International Seismological Center (ISC), EHB (groomed version of ISC bulletin), United States Geological Survey (USGS), Indian Meteorological Division (IMD) and Pakistan Meteorological Division (PMD). Apart from giving detailed information about time (year, month, day, hour, minute and second) and location (latitude, longitude and depth), different magnitude types (Ms, mb and ML) reported in the sources have been converted into moment magnitude $\left(M_{\mathrm{w}}\right)$. This earthquake catalogue is used as an input for source zone free layer-wise probabilistic hazard analysis. Layer-wise seismicity smoothening was applied to the epicenters of this earthquake catalogue to determine the activity rates for each magnitude interval using the approach of Woo (1996). Owing to the seismo-tectonic complexity of the NW Himalaya, the catalogue was divided into shallow $(0-25 \mathrm{~km})$, intermediate $(25-70 \mathrm{~km})$ and deep to very deep $(>70 \mathrm{~km})$ hypocentral depth.
These depth-range wise smoothened catalogues were used as zone free point sources for the depth-wise probabilistic seismic hazard analysis of the Kashmir basin.

On the basis of geology, tectonics and seismicity, Sana and Nath (2017) have identified five seismic source zones and carried out the detailed seismicity analysis of each seismic source zone and every major fault in the region. The five seismic source zone that have been delineated on the basis of above-mentioned criteria by Sana and Nath (2016a, b) are Hazara-Kashmir syntaxis seismic zone (HKS-SZ), Karakorum seismic zone (KM-SZ), Kohistan seismic zone (KH-SZ), Nanga Parbat syntaxis seismic zone (NPS-SZ) and the SE Kashmir seismic zone (SEK-SZ). Seismicity analysis includes evaluation of the Gutenberg-Richter parameters ( $a$-value and $b$-value) and estimation of $m_{\max }$ in present case using Kijko (2004). The $a$-value and $b$-value are important characteristic factors of seismicity of an area, defined by the classic magnitude-frequency relationship:

$$
\log _{10} N=a-b M
$$

where $N$ is the cumulative number of earthquakes with magnitude $\geq M$, (Guttenberg and Richter 1944). The magnitude-frequency relationship shows non-linearity at lower magnitudes, so a threshold magnitude $\left(M_{\mathrm{c}}\right)$ is used, which means only earthquakes with $M \geq M_{\mathrm{c}}$ are considered for seismicity analysis (Wiemer 2001). There are various methods to determine $b$-value; Sana and Nath (2016a, b) have used maximum likelihood estimation method:

$$
b=\frac{\log _{10}(e)}{M_{\text {mean }}-\left(M_{\mathrm{c}}-\frac{\Delta m}{2}\right)},
$$

where $M_{\text {mean }}$ is the average magnitude, $M_{\mathrm{c}}$ is the threshold magnitude and $\Delta m$ is the magnitude bin size (Aki 1965; Bender 1983; Utsu 1999). The $a$-value, $b$-value, $M_{\mathrm{c}}$ and $m_{\max }$ of each seismic source zone were determined. Figure 2 shows the seismic source zones of Kashmir basin and Table 1 shows the detailed seismicity analysis of each seismogenic zone. Additionally, seismicity analysis of each fault in and around the study region was carried out by Sana and Nath (2017); the $m_{\max }$ in this case was estimated by Wells and Coppersmith (1994) and is shown in Table 2.

\section{Ground motion prediction equations}

A ground motion prediction equation (GMPE) represents the relationship between the independent seismic parameters like the magnitude, the distance between the source and the site and a dependent ground shaking parameter like the peak ground acceleration (PGA) or pseudo-spectral acceleration (PSA). The appropriate 


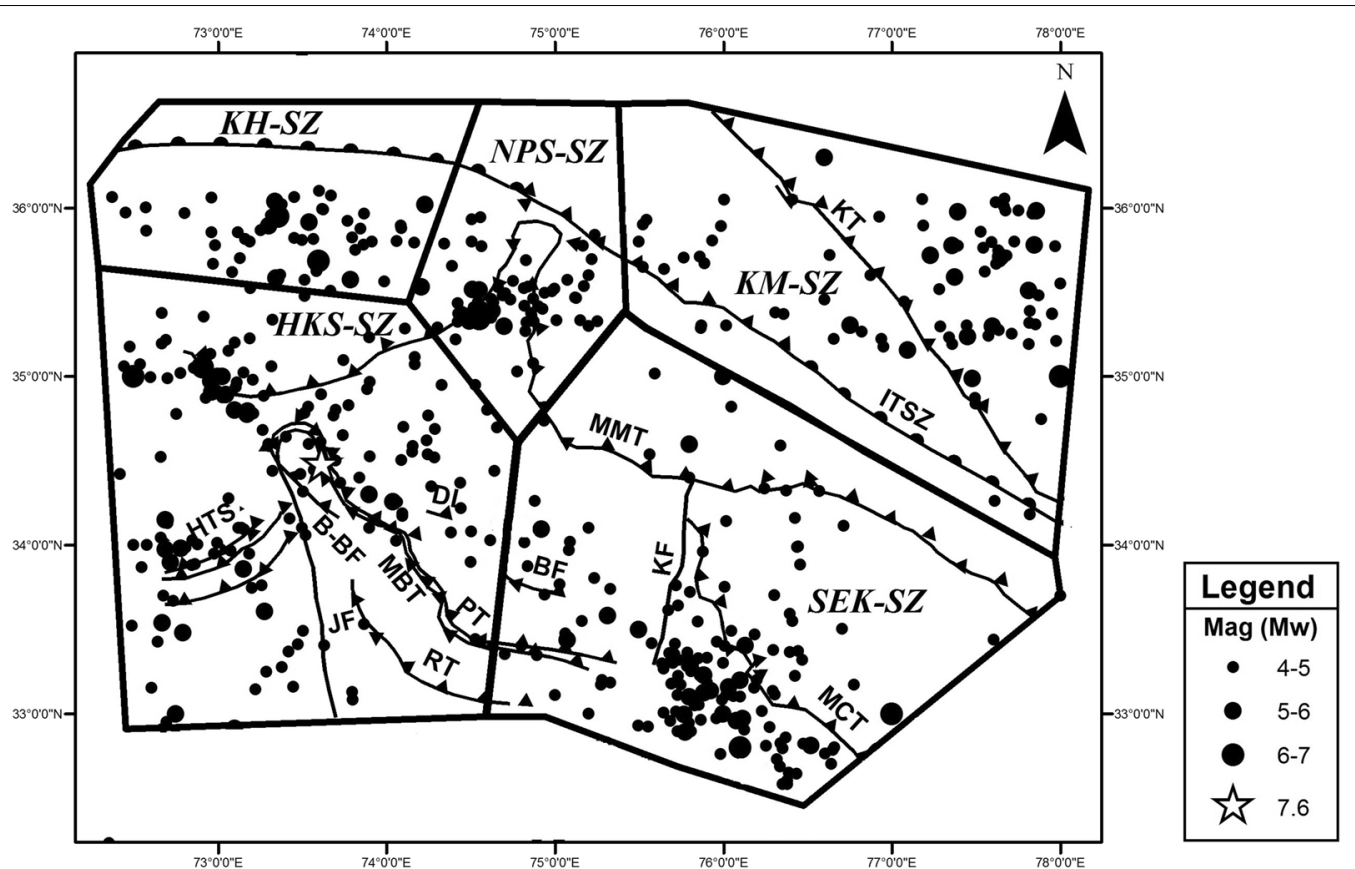

Fig. 2 The five seismic source zones considered for the probabilistic seismic hazard assessment of the Kashmir Basin: Hazara-Kashmir Syntaxis Seismic Zone (HKS-SZ), Nanga Parbat Syntaxis Seismic Zone (NPS-SZ), SE Kashmir-Seismic Zone (SEK-SZ), Kohistan Seismic Zone (KH-SZ) and Karakorum Seismic Zone (KM-SZ) after Sana and Nath (2017)

Table 1 Showing seismicity analysis results of all the seismic sources zones considered for PSHA of Kashmir basin

\begin{tabular}{llllll}
\hline Seismic zone & $\boldsymbol{a}$-value & $\boldsymbol{b}$-value & $\boldsymbol{m}_{\mathbf{c}}$ & $\boldsymbol{m}_{\max }$ & $\boldsymbol{m}_{\text {obs }}$ \\
\hline HKS-SZ & $6.11 \pm 0.57$ & $0.81 \pm 0.05$ & $3.9 \pm 0.05$ & $8.1 \pm 0.36$ & 7.6 \\
KM-SZ & $5.71 \pm 0.20$ & $0.79 \pm 0.01$ & $3.9 \pm 0.17$ & $7.3 \pm 0.58$ & 6.8 \\
KH-SZ & $5.95 \pm 0.15$ & $0.84 \pm 0.19$ & $4.3 \pm 0.35$ & $7.1 \pm 0.58$ & 6.6 \\
NPS-SZ & $7.86 \pm 0.26$ & $1.32 \pm 0.1$ & $4.4 \pm 0.01$ & $6.8 \pm 0.58$ & 6.3 \\
SEK-SZ & $8.12 \pm 0.38$ & $1.29 \pm 0.03$ & $4.7 \pm 0.17$ & $6.8 \pm 0.58$ & 6.3
\end{tabular}

$a$-value (for the whole time period) and $b$-value are Gutenberg-Richter seismicity parameters, magnitude of completeness $\left(m_{\mathrm{c}}\right)$ and maximum credible earthquakes $\left(m_{\max }\right)$ and maximum observed earthquake $\left(m_{\text {obs }}\right)$ of all the seismic zones of Greater Kashmir after Sana and Nath (2017). The Seismogenic zones are: Hazara-Kashmir Syntaxis Seismic Zone (HKS-SZ), Nanga Parbat Syntaxis Seismic Zone (NPS-SZ), SE Kashmir-Seismic Zone (SEK-SZ), Kohistan Seismic Zone (KH$\mathrm{SZ}$ ) and Karakorum Seismic Zone (KM-SZ)

ground motion prediction equations are not only useful in the rapid hazard assessment, but also critical for probabilistic seismic hazard analysis (Douglas 2003). Studies indicate that ground motions produced by earthquakes of similar sources within a similar type of tectonic setup are comparable. Thus, in regions lacking GMPE models, models from analogous regions are borrowed and used (Mueller et al. 2015). As the study region lacks GMPEs the tectonic setup appropriate ground motion prediction equations of Boore and Atkinson (2008), Campbell and
Bozorgnia (2008) and Sharma et al. (2009) were used. In general, the GMPEs developed for regions with tectonically active shallow crust show conformity (Nath and Thingbaijam 2011). The equations of Boore and Atkinson (2008) and Campbell and Bozorgnia (2008) were developed for areas with active tectonic setup using the PEER NGA (Pacific Earthquake Engineering Research Center's Next Generation Attenuation) strong motion database, whereas Sharma et al. (2009) used seismic data from Indian Himalaya and Zagros region of Iran. Boore and Atkinson's (2008) GMPE is for average-horizontal ground motions as a function of moment magnitude $\left(M_{\mathrm{w}}\right)$, closest horizontal distance from the source to site $\left(R_{\mathrm{JB}}\right)$, local average shear-wave velocity up to $30 \mathrm{~m}\left(V_{\mathrm{s}} 30\right)$, and type of the fault. Campbell and Bozorgnia (2008) model estimates PGA, PGV (peak ground velocity), PGD (peak ground displacement) and linear response spectra ( $T=0.01-10 \mathrm{~s})$ for shallow continental earthquakes for western North America and similar tectonic regimes. The variables of this GMPE are magnitude, closest distance to co-seismic rupture, style-of-faulting, hanging-wall effects and shallow linear and non-linear shear-wave velocity of the site. Finally, Sharma et al. (2009) is developed with respect to magnitude, shear-wave velocity site class and the style-of-faulting. These GMPEs have been used in the probabilistic seismic hazard assessment of Himalaya (Nath and Thingbaijam 2012; Sitharam 2014); also 
Table 2 Showing seismicity parameters, magnitude of completeness $\left(M_{c}\right)$ and $m_{\max }$ of all the major faults in and around the Kashmir basin from Sana and Nath (2017)

\begin{tabular}{llllll}
\hline Fault & $\begin{array}{l}\text { Starting year } \\
\text { of catalogue }\end{array}$ & $\begin{array}{l}\boldsymbol{a} \text {-value (entire time } \\
\text { period) }\end{array}$ & $\boldsymbol{b}$-value & $\boldsymbol{M}_{\mathbf{c}}$ & $\boldsymbol{m}_{\mathbf{m a x}} \mathbf{( \pm 0 . 2 8 )}$ \\
\hline ITSZ & 1965 & 4.99 & $0.70 \pm 0.04$ & $3.8 \pm 0.03$ & 7.6 \\
HTS & 1966 & 8.48 & $1.43 \pm 1.17$ & $4.5 \pm 0.44$ & 7.2 \\
Jhelum & 1965 & 6.16 & $1.09 \pm 0.53$ & $4.1 \pm 0.23$ & 7.0 \\
Karakorum & 1937 & 5.10 & $0.80 \pm 0.14$ & $4.0 \pm 0.24$ & 7.5 \\
Kishtwar & 1967 & 6.31 & $1.10 \pm 0.98$ & $3.9 \pm 0.37$ & 6.8 \\
MBT & 1945 & 4.38 & $0.50 \pm 0.07$ & $3.3 \pm 0.28$ & 7.4 \\
Panjal thrust & 1963 & 4.38 & $0.50 \pm 0.07$ & $3.3 \pm 0.28$ & 7.4 \\
MMT & 1937 & 7.38 & $1.15 \pm 0.13$ & $4.5 \pm 0.11$ & 7.7 \\
Reasi thrust & 1970 & 4.79 & $1.01 \pm 0.15$ & $3.5 \pm 0.42$ & 7.0 \\
MCT & 1947 & 3.96 & $0.53 \pm 0.03$ & $3.0 \pm 0.11$ & 7.2
\end{tabular}

Boore and Atkinson (2008) is recommended by NCSDP (National Committee on Seismic Design Parameters) for site-specific seismic hazard assessment of river valley power projects in the Himalaya (2011). The GMPEs were adopted according to the logic tree shown in Fig. 3.

Site conditions play an important role in seismic hazard assessment. For seismic hazard assessment at a site, usually NEHRP (National Earthquake Hazards Reduction
Program) site classification is used, which is based on average shear wave velocity $(\mathrm{m} / \mathrm{s})$ for the $30 \mathrm{~m}$-deep soil column from the surface (BSSC 2001). For regional hazard computations in Indian context, Nath and Thingbaijam (2012) propose firm-rock conditions (standard engineering bedrock) to be more realistic for hazard evaluation. So, in this study, we consider standard engineering bedrock for hazard computations, which corresponds



Fig. 3 The logic tree framework for the probabilistic seismic hazard assessment of the Kashmir basin, showing seismic sources zones and faults as seismic sources, seismicity analysis which includes evaluation of Gutenberg and Richter parameters (G-R) and maximum credible earthquake ( $\left.m_{\max }\right)$ and application of ground motion prediction equations, assigned weights are given in brackets 



Fig. 4 The predicted peak ground acceleration (PGA) distribution estimated for hypocentral depth ranges of 0-25 km, 25-70 km and >70 km. The computation is based on smoothly-gridded seismicity for each depth zone with a return period of 475 years
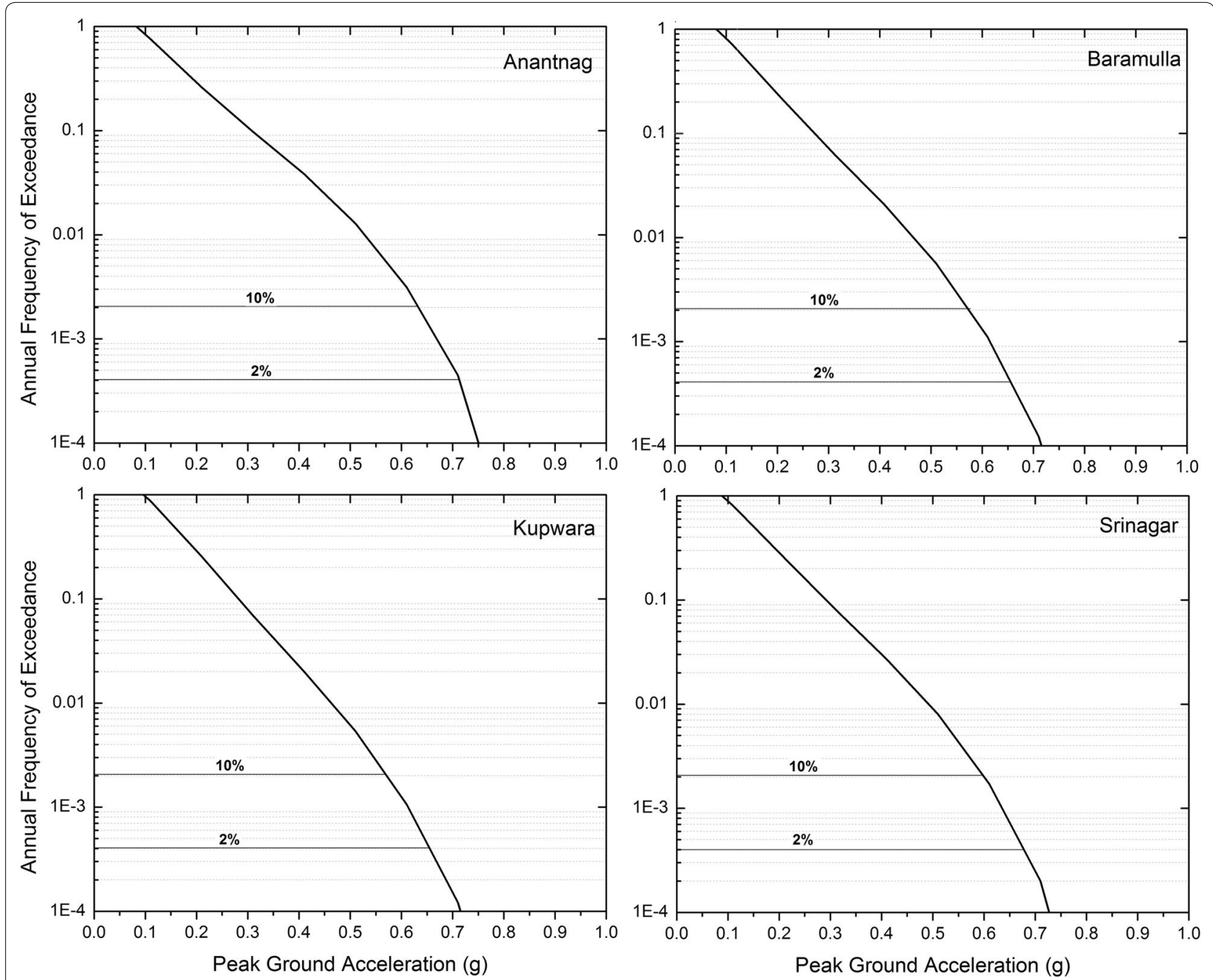

Fig. 5 The seismic hazard curve for predicted peak ground acceleration (PGA) in g for Anantnag, Baramulla, Kupwara and Srinagar, the major towns of Kashmir basin, showing $2 \%$ and $10 \%$ probability in 50 years for engineering bed rock sites 
Table 3 Predicted peak ground acceleration (PGA) in $g$ of major towns in Kashmir basin with $10 \%$ probability of exceedance in $\mathbf{5 0}$ years

\begin{tabular}{llll}
\hline Town & Latitude $\left({ }^{\circ} \mathbf{N}\right)$ & Longitude $\left({ }^{\circ} \mathrm{E}\right)$ & PGA $(\boldsymbol{g})$ \\
\hline Anantnag & 33.72 & 75.11 & 0.65 \\
Baramulla & 34.20 & 74.33 & 0.59 \\
Kupwara & 34.53 & 74.25 & 0.58 \\
Srinagar & 34.11 & 74.67 & 0.60 \\
\hline
\end{tabular}

to $V_{\mathrm{s}}$ of $760 \mathrm{~m} / \mathrm{s}$ and is defined as the boundary between site class B and C of NEHRP classification.

\section{Results and conclusion}

Due to the complex tectonic setup surrounding the region (Sana and Nath 2017), the hypocentral depthwise distribution of predicted PGA $(g)$ at $10 \%$ probability of exceedance in 50 years was carried out and is shown in Fig. 4. The depth-wise smoothly gridded zone free seismicity is considered as the sources in this case. The hypocentral depths are distributed into $0-25 \mathrm{~km}$ (upper crust), $25-70 \mathrm{~km}$ (lower crust) and $>70 \mathrm{~km}$ (intra-slab and subduction earthquakes) zones. All the three hypocentral zones contribute to the seismic hazard of Kashmir basin, with highest to lowest contribution from $>70 \mathrm{~km}$, $25-70 \mathrm{~km}$ and $0-25 \mathrm{~km}$, respectively. As depicted in Fig. 4, the basin as a whole is susceptible to very high seismic hazard. However, SE part of Kashmir basin is of relatively higher value of predicted PGA than the NW part but there is not much of a difference in the predicted
PGA value. As the ground motions with $\mathrm{PGA} \geq 0.3 \mathrm{~g}$ are considered more destructive to engineering structures (Christenson 1994), the contribution to destructive ground motions in descending order is $>70 \mathrm{~km}$ zone followed by $25-70 \mathrm{~km}$, and $0-25 \mathrm{~km}$.

With the delineated seismogenic zones and faults as sources, the seismic hazard curves with an annual frequency of exceedance for four major towns of the Kashmir basin: Anantnag, Baramulla, Kupwara and Srinagar are shown in Fig. 5 and the predicted PGA $(g)$ in Table 3 . All the towns show a very high seismic hazard and Anantnag shows the highest $(0.6 \mathrm{~g})$. The seismic hazard maps (PGA and PSA) of Kashmir basin are shown as Figs. 6, 7 and 8. The computation is performed for $2 \%$ and $10 \%$ probability of exceedance in 50 years, corresponding to a return period of 474 years and 2475 years, and PSA is computed at 0.2 and $1 \mathrm{~s}$. From the hazard maps, it is evident that overall Kashmir basin shows a high seismic hazard. Within the basin, southeastern part shows a higher hazard as compared to northwestern part. The design response spectra at 5\% damping for above mentioned major towns are shown in Fig. 9. The spectra were plotted using the methodology recommended by BIS (2002) using PSA at 0.2 and $1 \mathrm{~s}$ for a $10 \%$ probability of exceedance.

This study presents probabilistic seismic hazard analysis of the Kashmir basin, NW Himalaya based on the Sana and Nath (2017) earthquake catalogue. The contribution from zone free seismicity, seismic source zones and faults are considered from different perspectives using appropriate ground motion prediction equations



Fig. 6 The seismic hazard maps with faults and seismic source zones as sources, showing predicted peak ground acceleration (PGA) in g with 2\% and $10 \%$ probability of exceedance within 50 years for engineering bed rock sites 

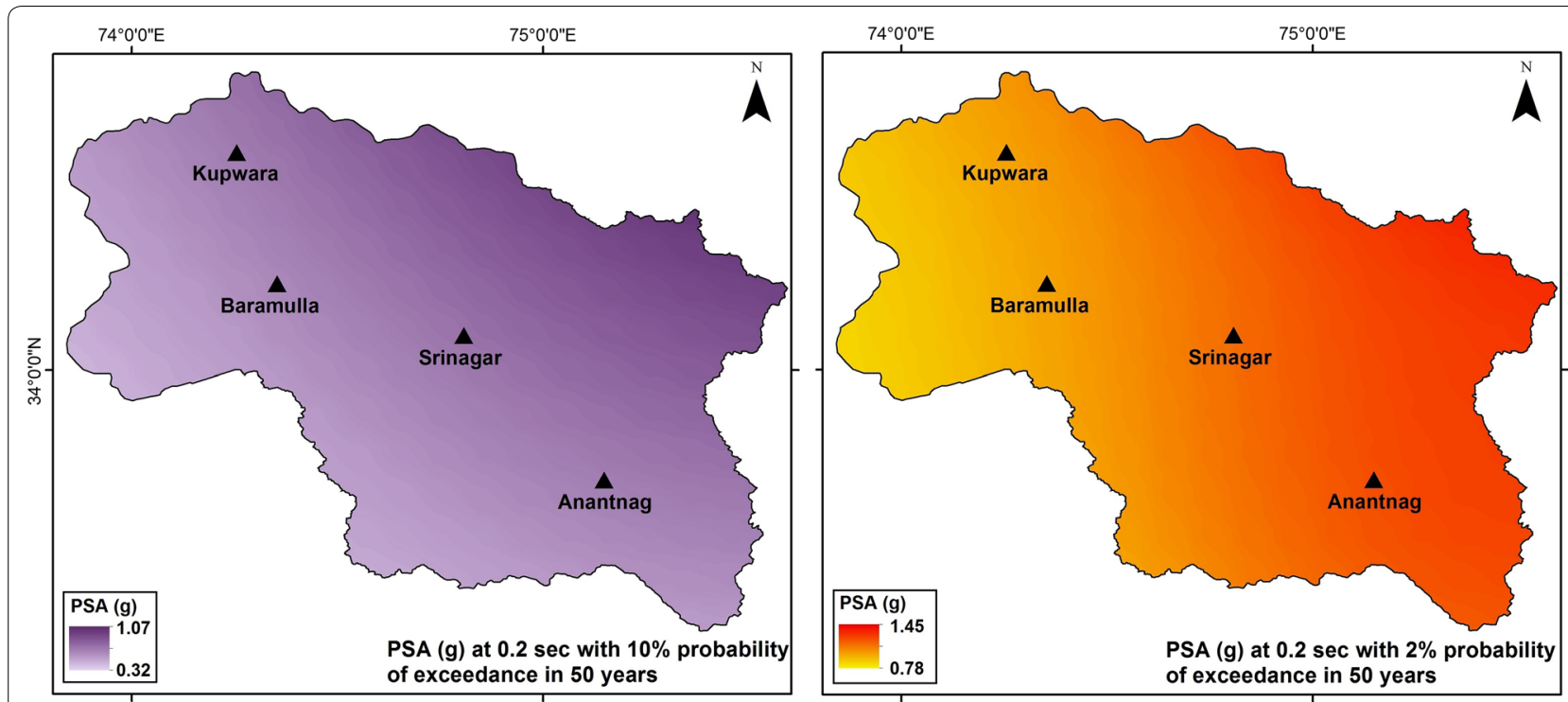

Fig. 7 The seismic hazard maps showing predicted pseudo spectral acceleration (PSA) in $g$ at $0.2 \mathrm{~s}(\mathrm{~s})$ with $2 \%$ and $10 \%$ probability of exceedance within 50 years for engineering bed rock sites. The sources are faults and seismic sources zones are considered sources for this computation
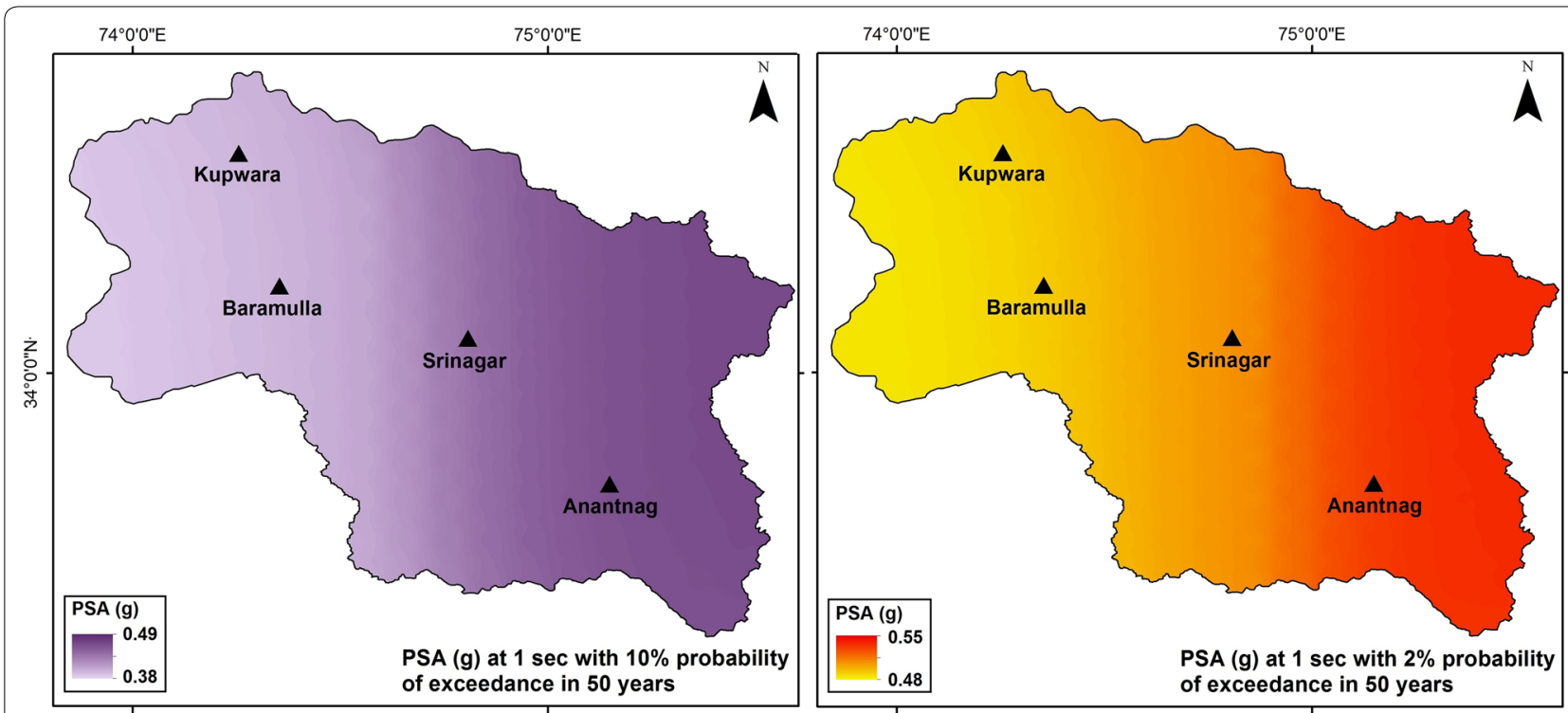

Fig. 8 The seismic hazard maps showing predicted pseudo spectral acceleration (PSA) in $g$ at $1 \mathrm{~s}(\mathrm{~s})$ with 2\% and 10\% probability of exceedance within 50 years for engineering bed rock sites. The sources are faults and seismic sources zones are considered sources for this computation

and the hazard is computed at different probabilities of exceedance. The present study advocates a significantly higher seismic hazard as compared to the BIS (2002). This study also recommends active fault and paleoseismic studies in the region, the outputs of which will not only refine the seismic hazard assessment models but also make them more realistic. As for example in this study and all the seismicity based seismic hazard models, the contribution from every fault in and around the region is given equal weightage, whereas in reality, the active faults are the actual contributors to the seismic hazard. 

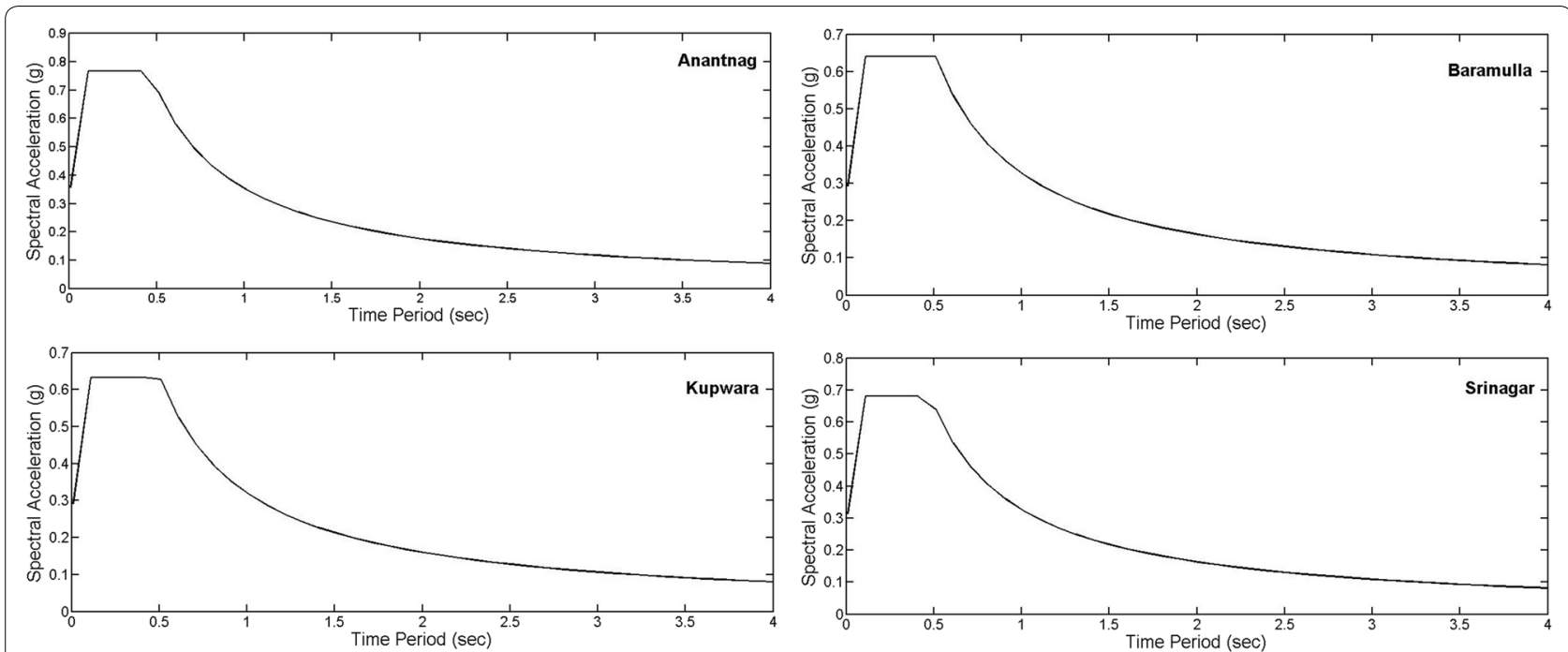

Fig. 9 Design response spectra with 5\% damping for major towns of Kashmir basin: Anantnag, Baramulla, Kupwara and Srinagar

\section{Authors' contributions}

All the analysis, figure plotting and write up of the manuscript were done by the author. The author read and approved the final manuscript.

\section{Acknowledgements}

I'm grateful to Sankar K. Nath for reading the first draft of this manuscript, Scott Callaghan (University of Southern California, California) for his insightfu comments and Arbind K. Yadav for his generous help in coding of the PSHA model for the Kashmir basin. I'm also grateful to the two anonymous reviewers, their comments helped greatly in the improvement of the quality of this manuscript.

\section{Competing interests}

The author declares that he has no competing interests.

\section{Availability of data and materials}

All the data used in this paper came from the published and unpublished sources listed in the references.

\section{Funding}

I am thankful to University Grants Commission, India for CSIR-UGC (JRF) NET Fellowship and Institute of Rock Structure and Mechanics, CAS for Long Term Conceptual Development Research Organization for the grant (Grant No: RVO:67985891).

\section{Publisher's Note}

Springer Nature remains neutral with regard to jurisdictional claims in published maps and institutional affiliations.

Received: 7 October 2018 Accepted: 19 April 2019

Published online: 30 April 2019

\section{References}

Ahmad B, Sana H, Alam A (2014) Macroseismic intensity assessment of 1885 Baramulla earthquake of northwestern Kashmir Himalaya, using the Environmental Seismic Intensity scale (ESI 2007). Quatern Int 321:59-64

Aki K (1965) Maximum likelihood estimate of $b$ in the formula $\log N=a-b M$ and its confidence limits. Bull Earthq Res Inst 43:237-239

Ambraseys N (2000) Reappraisal of north-Indian earthquakes at the turn of the 20th century. Curr Sci 79:101-114
Ambraseys N, Bilham R (2003) Earthquakes in Afghanistan. Seismol Res Lett 74:107-123

Ambraseys N, Douglas J (2004) Magnitude calibration of north Indian earthquakes. Geophys J Int 159:165-206

Avouac JP, Ayoub F, Leprince S, Konca O, Helmberger DV (2006) The 2005, $M_{w} 7.6$ Kashmir Earthquake: sub-Pixel correlation of ASTER images and seismic wave form analysis. Earth Planet Sci Lett 249:514-528

Bender B (1983) Maximum likelihood estimation of b-values for magnitude grouped data. Bull Seismol Soc Am 73:831-851

Bhatia SC, Kumar MR, Gupta HK (1999) A probabilistic seismic hazard map of India and adjoining regions. Ann Geophys 42(6):153-166

Bhatt DK (1989) Lithostratigraphy of Karewa group, Kashmir valley, India and a critical review of its fossil record. Memoirs Geol Surv India 122:3-9

BIS (2002) IS 1893-2002 (Part 1): Indian standard criteria for earthquake resistant design of structures. Part 1-general provisions and buildings. Bureau of Indian Standards, New Delhi

Boore DM, Atkinson GM (2008) Ground-motion prediction equations for the average horizontal component of PGA, PGV, and 5\%-damped PSA at spectral periods between $0.01 \mathrm{~s}$ and $10.0 \mathrm{~s}$. Earthquake Spectra 24:99-138

BSSC (Building Seismic Safety Council) (2001) NEHRP Recommended provisions for seismic regulations for new buildings and other structures. 2000 ed. Part 1: Provisions, Building Seismic Safety Council for the Federal Emergency Management Agency (Report FEMA 368), Washington, DC

Burbank DW (1983) The chronology of Intermontane-basin development in the northwestern Himalaya and the evolution of the Northwest Syntaxis. Earth Planet Sci Lett 64:77-92

Burbank DW, Johnson GD (1982) Intermontane-basin development in the past $4 \mathrm{My}$ in the north-west Himalaya. Nature 298:432-436

Burbank DW, Johnson GD (1983) The Late Cenozoic chronologic and stratigraphic development of the Kashmir Intermontane basin, northwestern Himalaya. Paleogeogr Paleoclimatol Paleoecol 43:205-235

Campbell KW, Bozorgnia Y (2008) NGA ground motion model for the geometric mean horizontal component of PGA, PGV, PGD and 5\% damped linear elastic response spectra for periods ranging from 0.01 to 10 s. Earthquake Spectra 24:139-171

Chevalier M-L, Ryerson FJ, Tapponnier P, Finkel RC, vander Woerd J, Haibing L, Qing L (2005) Slip-rate measurements on the Karakorum Fault may imply secular variations in fault motion. Science 307(5708):411-414. https://doi. org/10.1126/science.1105466

Christenson GE (1994) Ground Shaking in Utah. Utah Geol Surv Public Inf Series 29:1-4 
Cornell CA (1968) Engineering seismic risk analysis. Bull Seismol Soc Am 58:1583-1606

Cornell CA (1971) Probabilistic analysis of damage to structures under seismic loads. In: Howells DA, Haigh IP, Taylor C, editors. Dynamic waves in civil engineering. Proceedings of a conference organized by the Society for earthquake and civil engineering dynamics, Wiley, New York, pp 473-493

Dasgupta S, Pande P, Ganguly D, lqbal Z, Sanyal K, Venaktraman NV, Dasgupta S, Sural B, Harendranath L, Mazumdar K, Sanyal S, Roy A, Das LK, Misra PS, Gupta H (2000) Seismotectonic atlas of India and its environs. Geol Surv India Spec Publ 59:87

Douglas J (2003) Earthquake ground motion estimation using strong-motion records: a review of equations for the estimation of peak ground acceleration and response spectral ordinates. Earth Sci Rev 61(1-2):43-104

Guttenberg R, Richter CF (1944) Frequency of earthquakes in California. Bull Seism Soc Am 34:185-188

Hayes GP, Myers EK, Dewey JW, Briggs RW, Earle PS, Benz HM, Smoczyk GM, Flamme HE, Barnhart WD, Gold RD, Furlong KP (2017) Tectonic summaries of magnitude 7 and greater earthquakes from 2000 to 2015: U.S Geological Survey Open-File Report, vol. 2016-1192, p. 148. https://doi. org/10.3133/ofr20161192

Jones EA (1885) Report on the Kashmir earthquake of 30th May 1885. Rec Geol Surv India XVIII(4):221-227

Kazmi AH, Jan MQ (1977) Geology and Tectonics of Pakistan. Graphic Publishers, Karachi, p 545

Kijko A (2004) Estimation of the maximum earthquake magnitude Mmax. Pure Appl Geophys 161:1-27

Kramer SL (1996) Geotechnical earthquake engineering. Pearson Education Pvt. Ltd., London

McGuire RK (1976) FORTRAN computer program for seismic risk analysis, US Geological Survey, Open file report. vol. 76-67

Mueller C, Briggs R, Wesson R, Petersen M (2015) Updating the USGS seismic hazard maps for Alaska. Quatern Sci Rev 113:39-47. https://doi. org/10.1016/j.quascirev.2014.10.006

Nath SK, Thingbaijam KKS (2011) Peak ground motion predictions in India: an appraisal for rock sites. J Seismol 15:295-315

Nath SK, Thing baijam K (2012) Probabilistic seismic hazard assessment of India. Seismol Res Lett 83(1):135-149

NCSDP (2011) Guidelines for Preparation and submission of site-specific seismic study report of river valley project to National Committee on Seismic Design Parameters (NCSDP). Central Water Commission, Government of India, New Delhi

Parvez IA, Vaccari F, Panza GF (2003) A deterministic seismic hazard map of India and adjacent areas. Geophys J Int 155:489-508. https://doi. org/10.1046/j.1365-246X.2003.02052.x
Reiter L (1990) Earthquake Hazard Analysis-Issues and insights. Columbia University Press, New York, p 254

Sana H, Nath SK (2016a) Liquefaction potential analysis of the Kashmir valley alluvium, NW Himalaya. Soil Dyn Earthquake Eng 85:11-18

Sana H, Nath SK (2016b) In and Around the Hazara-Kashmir Syntaxis: a seismotectonic and seismic hazard perspective. J Indian Geophys Union 20(05):496-505

Sana H, Nath SK (2017) Seismic source zoning and maximum credible earthquake prognosis of the Greater Kashmir Territory, NW Himalaya. J Seismol 21(2):411-424

Sharma ML, Douglas J, Bungum H, Kotadia J (2009) Ground motion prediction equations based on data from the Himalayan and Zagros regions. J Earthquake Eng 13:1191-1210

Sitharam TG, Kolathayar S, James N (2014) Probabilistic assessment of surface level seismic hazard in India using topographic gradient as a proxy for site condition. Geosci Front 1:1. https://doi.org/10.1016/j.gsf.2014.06.002

Stephenson BJ, Searle MP, Waters DJ, Rex DC (2001) Structure of the Main Central Thrust zone and extrusion of the High Himalayan deep crustal wedge, Kishtwar-Zanskar Himalaya. J Geol Soc 158:637-652

Suckale J, Grünthal G, Regnier M, Bosse C (2005) Probabilistic seismic hazard assessment for Vanuatu. http://webdoc.sub.gwdg.de/ebook/serien/tm-v/ STR/0516.pdf

Szeliga W, Hough S, Martin S, Bilham R (2010) Intensity, magnitude, location, and attenuation in India for felt earthquakes since 1762. Bull Seismol Soc Am 100(2):570-584

Utsu T (1999) Representation and analysis of the earthquake size distribution: a historical review and some new approaches. Pure Appl Geophys 155:509-535

Ward SN (1994) A multidisciplinary approach to seismic hazard in southern California. Bull Seismol Soc Am 84:1293-1309

Wells DL, Coppersmith KJ (1994) New empirical relationships among magnitude, rupture length, rupture width, rupture area, and surface displacement. Bull Seismol Soc Am 84(4):974-1002

Wiemer S (2001) A software package to analyze seismicity: ZMAP. Seismol Res Lett 72(3):373-382

Woo G (1996) Kernel estimation methods for seismic hazard area source modeling. Bull Seismol Soc Am 86(2):353-362

Xu Z-Q, Dilek Y, Yang J-S, Liang F-H, Liu F, Ba D-Z, Cai Z-H, Li G-W, Dong H-W, Ji S-C (2015) Crustal structure of the Indus-Tsangpo suture zone and its ophiolites in southern Tibet. Gondwana Res 27(2):507-524

Yeats RS, Sieh K, Allen CR (1997) The geology of earthquakes. Oxford University Press, Oxford, p 450

\section{Submit your manuscript to a SpringerOpen ${ }^{\circ}$ journal and benefit from:}

- Convenient online submission

- Rigorous peer review

- Open access: articles freely available online

- High visibility within the field

Retaining the copyright to your article

Submit your next manuscript at springeropen.com 